\title{
Effect of Integrated Nutrient Management in Rice on Nitrogen Availability, L-asparaginase and L-glutaminase Activity in Acidic Soil
}

\author{
Abhik Patra ${ }^{1}$, V. K. Sharma ${ }^{1 *}$, T. J. Purakayastha ${ }^{1}$, Mandira Barman ${ }^{1}$, Sarvendra Kumar ${ }^{1}$, \\ D. Chakraborty ${ }^{2}$, Kapil A. Chobhe ${ }^{1}$ and D. J. Nath ${ }^{3}$ \\ ${ }^{1}$ Division of Soil Science and Agricultural Chemistry, ICAR-Indian Agricultural Research \\ Institute, New Delhi-110 012, India \\ ${ }^{2}$ Division of Agricultural Physics, ICAR-IARI, New Delhi 110 012, India \\ ${ }^{3}$ Department of Soil Science, Assam Agricultural University (AAU), \\ Jorhat, 785 013, Assam, India \\ *Corresponding author
}

A B S T R A C T

Keywords

Acid soil, L-

asparaginase activity,

L-glutaminase

activity, Long term

INM, Rice

Article Info

Accepted:

20 August 2017

Available Online:

10 September 2017
Long term field experiment on rice commenced in kharif 2006 at Instructionalcum-Research (ICR) farm of the Assam Agricultural University, Jorhat with integrated nutrient management (INM) treatments for assessing its impact on soil properties and microbial activities in acidic soils. The treatments consisted of $\mathrm{T}_{1}$; absolute control, $\mathrm{T}_{2} ; 100 \%$ recommended doses (RD) of inorganic NPK, $\mathrm{T}_{3} ; 50 \%$ $\mathrm{RD}$ of inorganic $\mathrm{NP}+100 \% \mathrm{~K}+$ biofertilizers, $\mathrm{T}_{4} ; 50 \% \mathrm{RD}$ of inorganic $\mathrm{NP}+$ $100 \% \mathrm{~K}+1$ tonne enriched compost $\mathrm{ha}^{-1}$ and $\mathrm{T}_{5} ; 25 \% \mathrm{RD}$ of inorganic NP + $100 \% \mathrm{~K}+2$ tonnes enriched compost $\mathrm{ha}^{-1}$. Results indicated that after 10 years of experiment, INM treatments with enriched compost as well as biofertilizers had pronounced influence on improving available nitrogen status as well as microbial enzymatic activity as compared to inorganic treatment under acid soil.

\section{Introduction}

Rice (Oryza sativa L.) is one of the most important cereal food crops of India in terms of area, production and consumer preference. India is the second largest producer and consumer of rice in the world. Productivity of rice in the diverse rainfed ecosystems of South and South-East Asia has not shown much improvement due to various factors. Low recovery of $\mathrm{N}$ to the extent of $30-40 \%$ is frequently encountered due to uncontrolled water accumulation in rice crop (Ghosh and Sharma, 1999). The continued use of inorganic fertilizers over the years in paddy field without application of organic amendments resulted in the change of soil structure as well as decreasing the soil fertility (Sannathimmappa et al., 2015).

One third of the soils of the world are acidic having $\mathrm{pH}<6.5$, and also $50 \%$ of the world's potentially cropped lands are acidic (Uexküll and Mutert, 1995). In India, around one-third of the cultivated soils are affected by soil acidity (Mandal, 1997). Most of these soils are from north-eastern region of India, with approximately $65 \%$ of area being under 
extreme soil acidity having $\mathrm{pH}$ below 5.5 (Sharma and Singh, 2002). Out of 142 million ha of arable land in India, 49 million ha covered by acid soils and spreading over 24 states of the country (34\% of cropped land in India) (Sharma and Singh, 2002 and Maji et al., 2012). Productivity of such soils are mainly constrained due to iron $(\mathrm{Fe})$ and aluminium (Al) toxicity, phosphorus (P) deficit, impaired biological activity, low base saturation and other acidity-induced soil plant nutritional and fertility problems (Kumar et $a l ., 2012)$.So, soil acidity negatively impacted on the production of staple food crops. This indicate the importance of soil acidity management and crop productivity improvement on such soils for enhancing food security regionally and globally.

Integrated nutrient management through use of inorganic fertilizers along with organic sources are applied to soil for increasing the status of plant available nutrients and improving the physico-chemical and biological properties of soil which directly affect soil fertility (Sannathimmappa et al., 2015). In contrast to nutrients in organic fertilisers, this required microbial metabolism to make most of them available to plants. So, inorganic fertilisers can directly affect crop growth and yields. Organic and inorganic fertilizer amendments are used primarily to increase nutrient availability to plants, but they can also affect soil microorganisms. Besides, the presence of these inorganic and organic substances in the soil is related with an increase in nutrient contents of soil and with their subsequent effects on soil properties such as microbial activity, the humus fraction, soil structure and cation exchange capacity (Kunc, 1988 and Kirchner et al., 1993). Therefore, INM may be a feasible approach to ensure the sustained availability of nitrogen and enhancing its use efficiency as well as microbial activity. Effect of integration of organic and inorganic inputs on important soil properties and microbial activities has been assessed in the present investigation.

\section{Materials and Methods}

\section{General information about experimental site}

The experiment started in 2006. The experimental site is located at Instructionalcum-Research (ICR) farm of the Assam Agricultural University, Jorhat. The latitude of the location $26^{\circ} 43^{\prime} \mathrm{N}$ and longitude $94^{\circ} 11^{\prime}$ E. The research site has a typical subtropical climate with a mean annual rainfall of 184.24 $\mathrm{cm}$ during the crop growing period, of which maximum mean annual rainfall was observed during July $(381.70 \mathrm{~cm})$. The minimum monthly mean temperature was $10.03^{\circ} \mathrm{C}$ in January and a maximum monthly mean temperature was $32.34^{\circ} \mathrm{C}$ in August. The experimental soil was Inceptisol with clay loam texture (28.6\% clay) and is classified as an Aeric Endoaquept, with dominant kaolintic minerals.

\section{Experimental details}

The experiment was laid down in randomized block design and replicated four times with five treatments. The plot size was $8 \times 5 \mathrm{~m}^{2}$. The treatments consisted of $\mathrm{T}_{1}$; absolute control, $\mathrm{T}_{2} ; 100 \%$ recommended doses (RD) of inorganic NPK, $\mathrm{T}_{3} ; 50 \% \mathrm{RD}$ of inorganic $\mathrm{NP}+100 \% \mathrm{~K}+$ biofertilizers, $\mathrm{T}_{4} ; 50 \% \mathrm{RD}$ of inorganic NP $+100 \% \mathrm{~K}+1$ tonne enriched compost $\mathrm{ha}^{-1}$ and $\mathrm{T}_{5} ; 25 \% \mathrm{RD}$ of inorganic NP $+100 \% \mathrm{~K}+2$ tonnes enriched compost $\mathrm{ha}^{-1}$. The recommended dose of inorganic fertilizers were 40:20:20 $\left(\mathrm{N}: \mathrm{P}_{2} \mathrm{O}_{5}: \mathrm{K}_{2} \mathrm{O} \mathrm{kg}\right.$ ha ${ }^{1}$ ) for rice. The sources of fertilizer for $\mathrm{N}, \mathrm{P}$ and $\mathrm{K}$ were urea, single superphosphate (SSP) and muriate of potash, respectively. The inorganic fertilizers were applied as per recommended package of practices. 
Biofertilizers viz., Azospirillum and phosphate solubilising bacteria (PSB) were applied as seedling root dip treatments which were kept for overnight. The enriched compost (EC) [primed with Azospirillum and PSB @ 1\% broth each containing $10^{8}-10^{9} \mathrm{cfu} . \mathrm{ml}^{-1}$ and adjusted with $1 \%$ rock phosphate (RP contained $19.46 \% \quad \mathrm{P}_{2} \mathrm{O}_{5}$ ) and cured for 1 month] was used in the experiment prepared from rice biomass. The rice variety Ranjit was transplanted on the second week of July 2015 with a row spacing of $20 \times 20 \mathrm{~cm}$.

\section{Soil processing and analysis}

The soil samples were collected after harvesting of rice during kharif 2015. The samples were separated into two parts; one part was processed for chemical analysis and the other part was preserved in refrigerator at $4^{\circ} \mathrm{C}$ for enzymatic analysis. The samples for chemical analysis were dried in shade, ground in wooden pestle-mortar, and sieved to pass through a $2 \mathrm{~mm}$ sieve. The $\mathrm{pH}$ of acid soil in 1:2 (soil: $\mathrm{KCl}$ ) suspension was determined by digital $\mathrm{pH}$ meter using combined electrode. Organic carbon content in soil was determined by wet oxidation method (Walkley and Black, 1934). Organic matter was calculated by using formula as given below:

Organic matter $\left(\mathrm{g} \mathrm{kg}^{-1}\right)=\%$ Organic carbon $\times$ $1.723 \times 10$

Available nitrogen in soil was determined by alkaline potassium permanganate $\left(\mathrm{KMnO}_{4}\right)$ method (Subbiah and Asija, 1956).Total nitrogen in soil was determined following the Kjeldahl method. The L-glutaminase activity and L-asparaginase activity in soil was measured by the method described by Kanazawa and Kiyota (1995) and extracted $\mathrm{NH}_{4}{ }^{+}$from solution was measured by the modified Nessler method (Omura et al., 1987). Statistical analysis of data was done using SAS-9.3.

\section{Results and Discussion}

\section{pH ${ }_{(\mathrm{KCl})}$ and organic matter}

As soil $\mathrm{pH}$ is one of the most important factors which governs the availability of plant nutrient in soil, the effect of application of enriched compost on soil $\mathrm{pH}_{(\mathrm{KCl})}$ was studied (Table 1). There was no significant effect of organic, inorganic and integrated treatments on $\mathrm{pH}$ of the soil, at any soil depth. Though some numeric increase was observed in different treatments as compared to control

Result indicated that increasing levels of enriched compost application increases the organic matter content significantly in all three soil depth (Table 1). Among all the treatments, organic matter content of soil ranged from 14.9 to $19.5,12.5$ to 17.4 and 11.8 to $16.7 \mathrm{~g} \mathrm{~kg}^{-1}$ soil at three different soil depths i.e., $0-5 \mathrm{~cm}, 5-15 \mathrm{~cm}$ and $15-30 \mathrm{~cm}$, respectively after harvesting of rice crop. Highest organic matter content $\left(19.5 \mathrm{~g} \mathrm{~kg}^{-1}\right)$ was recorded with $25 \% \mathrm{RD}$ of $\mathrm{NP}+100 \% \mathrm{~K}$ + enriched compost @ $2 \mathrm{t} \mathrm{ha}^{-1}$ treatment at 0$5 \mathrm{~cm}$ soil depth. Organic matter content decreases gradually as soil depth increases under all treatments. Majumder et al., (2008) reported $24.3 \%$ higher SOC under NPK + FYM treatments as compared to control. Ros et al., (2003) and Sharma et al., (2015), also found the similar results. The higher organic matter under INM treatments might be due to the direct application of carbon input, which could be enhanced further through root exudates, root residue of rice and biofertilizers application (Banswasi and Bajpai, 2006).

\section{Available nitrogen and total nitrogen}

Available and total nitrogen as influenced by manuring and fertilization is presented in Table 2. Results showed that maximum available nitrogen content of $251 \mathrm{~kg} \mathrm{ha}^{-1}$ in post-harvest soil was recorded under $25 \% \mathrm{NP}$ 
$+100 \% \mathrm{~K}+$ enriched compost @ $2 \mathrm{t} \mathrm{ha}^{-1}$ treatment at $0-5 \mathrm{~cm}$ soil depth and minimum $\left(157 \mathrm{~kg} \mathrm{ha}^{-1}\right)$ in control at $15-30 \mathrm{~cm}$ soil depth. Available nitrogen content increased significantly with manuring and fertilization treatments in all three soil depths over control. Highest available nitrogen content $257 \mathrm{~kg} \mathrm{ha}^{-1}$ was found with $25 \% \mathrm{RD}$ of NP + 100\% K + enriched compost @ $2 \mathrm{t} \mathrm{ha}^{-1}$ and which was at par with the treatments consisting of $100 \%$ RD of NPK in all three soil depths. Total nitrogen content increased from $1.45 \mathrm{~g} \mathrm{~kg}^{-1}$ in control $(15-30 \mathrm{~cm})$ to 1.72 $\mathrm{g} \mathrm{kg}^{-1}$ in $25 \% \mathrm{NP}+100 \% \mathrm{~K}+$ enriched compost@2 tha ${ }^{-1}$ treatment at $0-5 \mathrm{~cm}$ soil depth. Total nitrogen content in all three soil depths i.e., $0-5,5-15$ and $15-30 \mathrm{~cm}$ was found $1.72,1.65$ and $1.62 \mathrm{~g} \mathrm{~kg}^{-1}$, respectively with the application of $25 \% \mathrm{NP}+100 \% \mathrm{~K}+$ enriched compost @ $2 \mathrm{tha}^{-1,}$ which was at par with $50 \% \mathrm{NP}+100 \% \mathrm{~K}+$ enriched compost @ $1 \mathrm{t} \mathrm{ha}^{-1}$ and 50\% NP + 100\% K + biofertilizer and it was found to be similar with $100 \%$ NPK $\left(1.66,1.62\right.$ and $1.54 \mathrm{~g} \mathrm{~kg}^{-1}$ at 0-5, 5-15 and $15-30 \mathrm{~cm}$ soil depth, respectively).

Table.1 Effect of integrated nutrient management on $\mathrm{pH}_{\mathrm{KCl}}$ and Organic matter of post-harvest soil

\begin{tabular}{|c|c|c|c|c|c|c|}
\hline \multirow[t]{2}{*}{ Treatments } & \multicolumn{3}{|c|}{$\mathrm{pH}_{\mathrm{KCl}}$} & \multicolumn{3}{|c|}{ Organic matter $\left(\mathrm{g} \mathrm{kg}^{-1}\right)$} \\
\hline & $0-5 \mathrm{~cm}$ & $5-15 \mathrm{~cm}$ & $15-30 \mathrm{~cm}$ & $0-5 \mathrm{~cm}$ & $5-15 \mathrm{~cm}$ & $15-30 \mathrm{~cm}$ \\
\hline Control & 3.70 & 3.85 & 4.05 & $14.9^{\mathrm{C}}$ & $12.5^{\mathrm{C}}$ & $11.8^{\mathrm{C}}$ \\
\hline $100 \%$ RD of NPK & 3.75 & 3.92 & 4.16 & $17.6^{\mathrm{AB}}$ & $15.3^{\mathrm{AB}}$ & $14.2^{\mathrm{B}}$ \\
\hline $\begin{array}{l}50 \% \text { RD of NP + } 100 \% \mathrm{~K}+ \\
\text { Biofertilizers }\end{array}$ & 3.81 & 3.98 & 4.22 & $16.1^{\mathrm{BC}}$ & $14.7^{\mathrm{BC}}$ & $13.6^{\mathrm{BC}}$ \\
\hline $\begin{array}{l}50 \% \text { RD of NP }+100 \% \mathrm{~K}+ \\
\text { Enriched compost @ } 1 \mathrm{tha}^{-1}\end{array}$ & 3.89 & 4.11 & 4.28 & $18.8^{\mathrm{A}}$ & $16.4^{\mathrm{AB}}$ & $15.5^{\mathrm{AB}}$ \\
\hline $\begin{array}{l}25 \% \mathrm{RD} \text { of } \mathrm{NP}+100 \% \mathrm{~K}+ \\
\text { Enriched compost @ } 2 \mathrm{t} \mathrm{ha}^{-1}\end{array}$ & 3.94 & 4.25 & 4.34 & $19.5^{\mathrm{A}}$ & $17.4^{\mathrm{A}}$ & $16.7^{\mathrm{A}}$ \\
\hline Mean & 3.82 & 4.02 & 4.21 & 17.4 & 15.3 & 14.4 \\
\hline LSD@ 5\% & NS & NS & NS & 2.70 & 2.19 & 2.19 \\
\hline
\end{tabular}

Table.2 Effect of integrated nutrient management on available and Total nitrogen of post-harvest soil

\begin{tabular}{|c|c|c|c|c|c|c|}
\hline \multirow[t]{2}{*}{ Treatments } & \multicolumn{3}{|c|}{ Available Nitrogen $\left(\mathrm{kg} \mathrm{ha}^{-1}\right)$} & \multicolumn{3}{|c|}{ Total Nitrogen $\left(\mathrm{g} \mathrm{kg}^{-1}\right)$} \\
\hline & $\begin{array}{c}0-5 \\
\mathrm{~cm}\end{array}$ & $\begin{array}{c}5-15 \\
\text { cm }\end{array}$ & $\begin{array}{l}15-30 \\
\mathrm{~cm}\end{array}$ & $\begin{array}{c}\mathbf{0 - 5} \\
\mathrm{cm}\end{array}$ & $\begin{array}{l}5-15 \\
\mathrm{~cm}\end{array}$ & $15-30 \mathrm{~cm}$ \\
\hline Control & $180^{\mathrm{D}}$ & $173^{\mathrm{D}}$ & $157^{\mathrm{B}}$ & 1.50 & 1.49 & 1.45 \\
\hline $100 \%$ RD of NPK & $242^{\mathrm{AB}}$ & $221^{\mathrm{AB}}$ & $179^{\mathrm{A}}$ & 1.66 & 1.62 & 1.54 \\
\hline $\begin{array}{l}50 \% \text { RD of NP + } 100 \% \mathrm{~K}+ \\
\text { Biofertilizers }\end{array}$ & $223^{C}$ & $196^{\mathrm{C}}$ & $162^{\mathrm{B}}$ & 1.59 & 1.56 & 1.48 \\
\hline $\begin{array}{l}50 \% \text { RD of NP }+100 \% \mathrm{~K}+ \\
\text { Enriched compost @ } 1 \mathrm{t} \mathrm{ha}^{-1}\end{array}$ & $230^{\mathrm{BC}}$ & $211^{\mathrm{BC}}$ & $171^{\mathrm{AB}}$ & 1.60 & 1.57 & 1.51 \\
\hline $\begin{array}{l}25 \% \mathrm{RD} \text { of } \mathrm{NP}+100 \% \mathrm{~K}+ \\
\text { Enriched compost @ } 2 \mathrm{t} \mathrm{ha}^{-1}\end{array}$ & $251^{\mathrm{A}}$ & $234^{\mathrm{A}}$ & $184^{\mathrm{A}}$ & 1.72 & 1.65 & 1.62 \\
\hline Mean & 225 & 207 & 171 & 1.61 & 1.58 & 1.52 \\
\hline LSD @ 5\% & 18.0 & 17.0 & 15.9 & NS & NS & NS \\
\hline
\end{tabular}


Table.3 Effect of integrated nutrient management of L-asparaginase and L-glutaminase activity in post-harvest soil

\begin{tabular}{|c|c|c|c|c|c|c|}
\hline \multirow[t]{2}{*}{ Treatments } & \multicolumn{3}{|c|}{$\begin{array}{c}\text { L-asparaginase } \\
\left(\mu \mathrm{g} \mathrm{NH}_{4}^{+} \mathrm{g}^{-1} \text { soil }^{-1}\right)\end{array}$} & \multicolumn{3}{|c|}{$\begin{array}{c}\text { L-glutaminase } \\
\left(\mu \mathrm{g} \mathrm{NH}_{4}^{+} \mathrm{g}^{-1} \text { soil }^{-1}\right)\end{array}$} \\
\hline & $0-5 \mathrm{~cm}$ & $5-15 \mathrm{~cm}$ & $15-30 \mathrm{~cm}$ & $0-5 \mathrm{~cm}$ & $5-15 \mathrm{~cm}$ & $15-30 \mathrm{~cm}$ \\
\hline Control & $35.4^{\mathrm{C}}$ & $30.3^{\mathrm{B}}$ & $27.9^{\mathrm{B}}$ & $117^{\mathrm{C}}$ & $108^{C}$ & $94.8^{\mathrm{B}}$ \\
\hline $100 \%$ RD of NPK & $42.2^{\mathrm{AB}}$ & $37.5^{\mathrm{A}}$ & $35.1^{\mathrm{A}}$ & $129^{\mathrm{A}}$ & $121^{\mathrm{AB}}$ & $107^{\mathrm{A}}$ \\
\hline $50 \%$ RD of $\mathrm{NP}+100 \%$ & $38.9^{\mathrm{BC}}$ & $35.6^{\mathrm{A}}$ & $34.0^{\mathrm{A}}$ & $121^{\mathrm{BC}}$ & $117^{\mathrm{B}}$ & $103^{\mathrm{A}}$ \\
\hline $\begin{array}{l}\text { K + Biofertilizers } \\
50 \% \text { RD of NP + } 100 \% \\
\text { K + Enriched compost @ } \\
1 \text { t ha } \text {-1 }^{-10}\end{array}$ & $41.0^{\mathrm{B}}$ & $35.4^{\mathrm{A}}$ & $33.2^{\mathrm{A}}$ & $126^{\mathrm{AB}}$ & $119^{\mathrm{AB}}$ & $106^{\mathrm{A}}$ \\
\hline $\begin{array}{l}25 \% \mathrm{RD} \text { of } \mathrm{NP}+100 \% \\
\mathrm{~K}+\text { Enriched compost } @ \\
2 \mathrm{t} \mathrm{ha}\end{array}$ & $45.3^{\mathrm{A}}$ & $37.8^{\mathrm{A}}$ & $35.8^{\mathrm{A}}$ & $132^{\mathrm{A}}$ & $124^{\mathrm{A}}$ & $109^{\mathrm{A}}$ \\
\hline Mean & 40.5 & 35.3 & 33.2 & 125 & 118 & 104 \\
\hline LSD@ & 3.58 & 3.68 & 2.98 & 7.68 & 5.95 & 7.15 \\
\hline
\end{tabular}

Application of Farm Yard Manure (FYM) alone and integration with inorganic fertilizers play a vital role in exploiting high yield potential through its beneficial effect on nutrients supply and chemical and biological properties (Sharma et al., 2016).

Increase in available $\mathrm{N}$ both in surface and sub-surface soils might be ascribed to the fact that addition of mineral $\mathrm{N}$ along with organic source narrowed the $\mathrm{C}$ : $\mathrm{N}$ ratio of organic manure and this enhanced the rate of mineralization resulting in rapid conversion of organically bound $\mathrm{N}$ to inorganic forms and helped in release of nutrients from the organic matter.

This finding was in agreement with the reports of Singh et al., (2006). The positive balance in available soil $\mathrm{N}$ is likely attributed to the positive balance of total SOM and might have been partially due to a slow release of $\mathrm{N}$ from enriched compost products.

The present results are in agreement with other workers (Bhandari et al., 2002).

\section{Microbial activities}

The L-asparaginase and L-glutaminase activity of post-harvest soil as influenced by manuring and fertilization is presented in (Table 3). The results showed significant enhancement in activity of L-asparaginase in post-harvest soil from $35.4,30.3$ and $27.9 \mu \mathrm{g}$ $\mathrm{NH}_{4}^{+} \mathrm{g}^{-1}$ soil $\mathrm{h}^{-1}$ in control to $45.3,37.8$ and $35.8 \mu \mathrm{g} \mathrm{NH}_{4}^{+} \mathrm{g}^{-1}$ soil h$^{-1}$ in $25 \% \mathrm{NP}+100 \% \mathrm{~K}$ + enriched compost @ $2 \mathrm{t} \mathrm{ha}^{-1}$ at 0-5, 5-15 and $15-30 \mathrm{~cm}$ soil depth, respectively. At 0-5 soil depth L-asparaginase activity $(45.3 \mu \mathrm{g}$ $\mathrm{NH}_{4}{ }^{+} \mathrm{g}^{-1}$ soil $\mathrm{h}^{-1}$ ) in treatment $25 \% \mathrm{NP}+$ $100 \% \mathrm{~K}+$ enriched compost @ 2 t ha ${ }^{-1}$ was recorded significantly higher over rest of other treatments. But, in 5-15 and $15-30 \mathrm{~cm}$ soil depths any kind of integrated treatment effectively increased the L-asparaginase activity over control. L-glutaminase activity was significantly increased while application of 2 tonne enriched compost ha ${ }^{-1}$ with reduce doses of NP (132, 124 and $109 \mu \mathrm{g} \mathrm{NH}_{4}{ }^{+} \mathrm{g}^{-1}$ soil $\mathrm{h}^{-1}$ at $0-5,5-15$ and $15-30 \mathrm{~cm}$ soil depth, respectively) over control and this treatment was at per with $100 \%$ RD of NPK. 
L-glutamine and L-asparagine plays an important role in the nitrogen cycle in soils. L-glutamine is decomposed to L-glutamic acid and ammonia by L-glutaminase. Lasparagine is also decomposed to L-aspartic acid and ammonia by L-asparaginase (Ladd and Jackson 1982; Omura et al., 1987). Integrated use of chemical fertilizers and enriched compost brings in more enzyme activities in soil compared to only chemical fertilizers treated plot. Kumawat et al., 2017 also reported that crop residue retention as an organic source enhanced the microbial activities in rhizospheric soils. Fertilizers may meet the demand of mineral nutrition required by the microbes but not that of carbon, which is a major constituent of microbial cells (Ghosal and Singh, 1994). Integrated application of organic and inorganic materials provides a balanced supply of mineral nutrients as well as carbon. This is reflected in terms of increased levels of enzyme activities in soil receiving 25\% NP $+100 \% \mathrm{~K}+$ enriched compost@2 $\mathrm{tha}^{-1}$.

From investigation, it is concluded that the integrated treatments involving both inorganic fertilizers and organic sources had pronounced influence in improving available nitrogen status as well as microbial enzymatic activity as compared to recommended dose of fertilizers.

\section{References}

Banswasi, R., and Bajpai, R.K. 2006. Influence of organic and inorganic fertilizer sources on soil fertility, yield and nutrient uptake by wheat crop in a rice-wheat cropping system. Journal of Soils and Crops, 16: 300-304.

Bhandari, A. L., Ladha, J. K., Pathak, H., Padre, A. T., Dawe, D., and Gupta, R. K. 2002. Yield and soil nutrient changes in a longterm rice-wheat rotation in India. Soil Science Society of America Journal, 66: 162-170.

Ghosal, N., and Singh, K.P. 1995. The effects of farm-yard manure and inorganic fertilizers on the dynamics of soil microbial biomass in a tropical dryland agroecosystem. Biology and Fertility of Soils, 19: 231-238.

Ghosh, A., and Sharma, A.R., 1999. Effect of combined use of organic manure and nitrogen fertilizer on the performance of rice under flood-prone lowland conditions. The Journal of Agricultural Science, 132: 461-465.

Kanazawa, S., and Kiyota, H. 1995. Estimation of L-glutaminase and L-asparaginase activities in soils by the indophenol method. Soil Science and Plant Nutrition, 41: 305311.

Kirchner, M. J., Wollum, A. G., and King, L. D. 1993. Soil microbial populations and activities in reduced chemical input agroecosystems. Soil Science Society of America Journal, 57: 1289-1295.

Kumar, M., Baishaya, L. K., Ghosh, D. C., Gupta, V. K., Dubey, S. K., Das, A., and Patel, D. P. 2012. Productivity and soil health of potato (Solanum tuberosum L.) field as influenced by organic manures, inorganic fertilizers and biofertilizers under high altitudes of eastern Himalayas. Journal of Agricultural Science, 4: 223.

Kumawat, C., Sharma, V. K., Meena, M. C., Kumar, S., Barman, M., Chobhe, K. A. and Yadav R. K. 2017. Fluorescein Diacetate activity as affected by residue retention and $\mathrm{P}$ fertilization in maize under maize-wheat cropping system. International Journal of Current Microbiology and Applied Sciences, 6: 2571-2577.

Kunc, F., 1988. Three decades of heterocontinuous flow cultivation method in soil microbiology. Continuous culture. Academic Press, London, 43-55.

Ladd, J.N., and Jackson, R. B. 1982. Biochemistry of ammonification. In Nitrogen in Agricultural Soils, Eds.Stevenson, F.J.,Bremner, J.M., Hauck, R.D., and Keeney, D.R. 22: 186-187, Madison, Wisconsin,U.S.A.

Maji, B., Sahu, N. C., Das, I., Saha, S., Sarkar, S., and Saha, S. 2012. Soil fertility 
management for productivity enhancement of jute under some constrained acidic soils of West Bengal. Indian Journal of Agricultural Sciences, 82: 345-50.

Majumder, B., Mandal, B., and Bandyopadhyay, P. K. 2008. Soil organic carbon pools and productivity in relation to nutrient management in a 20 -year-old riceberseem agroecosystem. Biology and Fertility of Soils, 44: 451-461.

Mandal, S. C., 1997. Introduction and historical overview. Acidic Soils of India ( $E d s$. Mahapatra I. C., Mandal S. C., Misra C., Mitra G. N. and Panda N.) ICAR, New Delhi, 3-24.

Omura, H., Sato, F., Sasaki, I., and Muroi, E. 1987. Soil L-asparaginase activities in andosols. Japanese Journal of Soil Seience and Plant Nutrition, 58: 536-541 (in Japanese)

Ros, M., Hernandez, M. T., and Garcí, C. 2003. Soil microbial activity after restoration of a semiarid soil by organic amendments. Soil Biology and Biochemistry, 35: 463-469.

Sannathimmappa, H. G., Gurumurthy, B. R., Jayadeva, H. M., Rajanna, D. and Shivanna, M.B. 2015. Effect of Paddy Straw Based Integrated Nutrient Management Practices for Sustainable Production of Rice. IOSR Journal of Agriculture and Veterinary Science, 8: 74-77.

Sharma, U. C., and Singh, R. P. 2002. Acid soils of India: their distribution, management and future strategies for higher productivity. Fertiliser News, 47: 45-52.

Sharma, V.K., Pandey, R. N., Kumar, S., Chobhe, K.A. and Chandra, S. 2016. Soil test crop response based fertilizer recommendations under integrated nutrient management for higher productivity of pearl millet (Pennisetum glaucum L.) wheat (Triticum aestivumL) under long term experiment. Indian Journal of Agricultural Sciences, 86: 1076-81.

Sharma, V.K., Pandey, R.N. and Sharma B.M. 2015. Studies on longterm impact of STCR based integrated fertilizer use on pearlmillet (Pennisetum glaucum L.)- Wheat (Triticum aestivum L) cropping system in semi-arid condition of India. Journal of Environmental Biology, 36: 241-247.

Singh, S., Singh, R. N., Prasad, J., and Singh, B. P. 2006. Effect of integrated nutrient management on yield and uptake of nutrients by rice and soil fertility in rainfed uplands. Journal of the Indian Society of Soil Science, 54: 327-330.

Subbiah, B., and Asija, G. L. 1956. A rapid procedure for estimation of available nitrogen in soils. Current Science, 25: 259260.

Von Uexküll, H. R., and Mutert, E. 1995. Global extent, development and economic impact of acid soils. In Plant-soil interactions at low $\mathrm{pH}$ : Principles and management (5-19). Springer Netherlands.

Walkley, A., and Black, I.A. 1934. An examination of the Degtijareff method for determining soil organic matter and a proposed modification of the chromic acid titration method. Soil Science, 37: 29-38.

\section{How to cite this article:}

Abhik Patra, V. K. Sharma, T. J. Purakayastha, Mandira Barman, Sarvendra Kumar, D. Chakraborty, Kapil A. Chobhe and Nath D. J. 2017. Effect of Integrated Nutrient Management in Rice on Nitrogen Availability, L-asparaginase and L-glutaminase Activity in Acidic Soil. Int.J.Curr.Microbiol.App.Sci. 6(9): 3777-3783. doi: https://doi.org/10.20546/ijcmas.2017.609.466 